\title{
Sustenance of Seed Germination Potential of Two Okra (Abelmoschus esculentus L. Moench) Varieties under Different Environmental Conditions in Sri Lanka
}

\author{
R,A.I.S. Ariyarathna ${ }^{*}$, S.L. Weerasena ${ }^{1}$ and C.K. Beneragama ${ }^{2}$ \\ ${ }_{1}^{1}$ Postgraduate Institute of Agriculture, University of Peradeniya, Peradeniya, Sri Lanka \\ ${ }^{2}$ Department of Crop Science, Faculty of Agriculture, University of Peradeniya, Peradeniya, Sri Lanka
}

ARTICLE INFO

\section{Article history:}

Received: 02 August 2019

Accepted: 16 October 2019

Available online: 1 December 2019

\section{Keywords:}

Field emergence

Germination

Seed survival

Storage conditions

Vigour index

\section{Citation:}

Ariyarathna, R,A.I.S., Weerasena, S.L. and Beneragama, C.K. (2020) Sustenance of Seed Germination Potential of Two Okra (Abelmoschus esculentus L. Moench) Varieties under Different Environmental Conditions in Sri Lanka. Tropical Agricultural Research, 31(1): 21-30

DOI: http://doi.org/10.4038/tar.v31i1.8341

Ariyarathna, R.A.I.S.

https://orcid.org/0000-0003-1445-9552

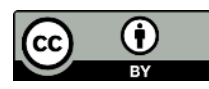

\begin{abstract}
Okra (Abelmoschus esculentus L. Moench) is a popular vegetable grown in most parts of Sri Lanka. Farmers and home gardeners purchase seeds in packed-form from retail outlets. However, quality problems are frequently reported, especially claiming low field germination even with the laboratory-tested and certified seeds. Quality parameters namely, percentage germination , moisture, field emergence and vigour index analysis were used to determine the effect of different storage environmental conditions on seed longevity of two okra varieties during a two-year storage period, from March 2016 to March 2018. Seeds in triple-laminated packets stored in four contrasting environments, namely, low temperature storage conditions $\left(17{ }^{\circ} \mathrm{C}\right.$ and $\left.60-65 \% \mathrm{RH}\right)$; three geoenvironmental conditions namely; Gannoruwa (Mid Country Wet Zone), Kundasale (Mid Country Intermediate Zone), and Mahallluppallama (Low Country Dry Zone) displayed varied behavior in seed quality parameters respective of the variety. It was apparent that germination test alone does not represent the full potential of field emergence. Results of the present study revealed that when field emergence and vigour are also taken in to account, both varieties of okra seed (with initial germination and moisture of $c a .94 \%$ and $c a .10 \%$ ) can be stored under ambient conditions at Gannoruwa, Kundasale or Mahallluppallama for a maximum period of 12 months, without compromising the seed quality. The seeds stored under low temperature conditions (i.e. $17{ }^{\circ} \mathrm{C}$ ), maintained the seed germination over $75 \%$ for a period of 24 months.
\end{abstract}

*Corresponding author: indira.ariyarathna@gmail.com 


\section{INTRODUCTION}

Okra (Abelmoschus esculentus L. Moench) is a popular vegetable grown in most parts of Sri Lanka with a total cultivated extent of 8,367 ha (Maha 2017/18 and Yala 2018), while producing 54,265 $\mathrm{mt}$ annually (Department of Census and Statistics, 2018). Certified seeds of okra are produced in Sri Lanka in seed farms of Department of Agriculture (DOA) and in related contracted farmer fields in different areas of the country. Seeds are processed at the Kundasale Processing center (Mid Country Intermediate Zone) and transported to Gannoruwa (Mid Country Wet Zone) for medium term storage. Seeds are then packed in to small quantities in triple laminated aluminium foil packs at Gannoruwa Vegetable Seed Center and are distributed throughout the country from their retail outlets from which, farmers and home gardeners purchase seeds. In addition, the certified seeds are stored at different agro-ecological regions in Sri Lanka. Seeds are exposed to prevailing ambient temperature and relative humidity at selling points for several months until they reach the farmer.

One of the common accusations from farmers who buy these certified and guaranteed seeds is that, the seeds do not germinate in the field as expected. It is well established that, the seed storage conditions affect the seed quality and their field performance (e.g. Singh et al, 2017). In addition, many investigators reported that the speed of decline in seed quality is largely dependent on seed quality at harvest, prestorage treatments, storage temperature, packing materials, relative humidity, seed moisture content, length of the storage and type of seeds (Walters and Roos, 1990, Yangpin et al., 2000; Gomez-Campo, 2006; Walters, 2007).

The temperature and relative humidity fluctuate differently with time in different agro-ecological regions in Sri Lanka (Punyawardhana, 2008). Ambient conditions in tropical regions are generally not ideal for seed storage thus maintaining the viability during storage is a herculean task (Ellis, 1991). The ability of crop seeds to retain their viability over extended period of uncontrolled temperature and/or $\mathrm{RH}$ conditions has not widely been investigated. Therefore, the present this study was conducted to elucidate the effect of contrasting storage environmental conditions where seeds are stored in Sri Lanka, on seed quality parameters and to determine the appropriate storage environmental conditions for okra seeds packed in triple laminated aluminum foil in Sri Lanka.

\section{MATERIALS AND METHODS}

Certified seed lots of two okra (Abelmoschus esculentus L. Moench) varieties; MI-5 and Haritha were used for the study. Initial germination percentage and moisture of MI-5 and Haritha were 94\%, 9.9\% and 93\%, 10.5\% respectively. Seed lots were obtained from DOA contracted farmers and $12 \mathrm{~kg}$ seeds of seed lots for each treatment were transported to Kundasale for processing. At Vegetable Seed Center (DOA) Gannoruwa, seed lots were packed in to triple laminated aluminium foil packs having $10 \mathrm{~g}$ of seeds in each packet as retails. Seed packets were stored at following locations representing three major agroclimatic zones of Sri Lanka; (a) Gannoruwa Vegetable Seed Centre (Mid Country Wet Zone), (b) Kundasale Seed Sales Centre (Mid Country Intermediate Zone) and (c) Mahailluppallama Seed Sales Centre (Low Country Dry Zone) of the DOA under ambient conditions. Further, same amount of retail packets were kept in low temperature condition $\left(17^{\circ} \mathrm{C}\right.$ at $\left.60 \%-65 \% \mathrm{RH}\right)$ at the cold storage facility of Seed Certification Service, Gannoruwa, as a control. All seed packs were sampled at monthly intervals over a period of 24 months and subjected to laboratory and field tests at Gannoruwa, Peradeniya. 
Standard laboratory tests were performed according to the guidelines of International Seed Testing Association (ISTA, 2015). The germination test was performed at the Central Seed Testing Laboratory (CSTL) on the prescribed sand media to plant $25 \times 4$ seeds per germination tray and was allowed to germinate inside a germination chamber at $25 \pm 1{ }^{\circ} \mathrm{C}$ with 8 hours light. Number of germinated seeds was counted on the $7^{\text {th }}$ day as the first count and similarly, on the $10^{\mathrm{h}}$ day of the germination as the final count. Normal seedling count was obtained on the $10^{\text {th }}$ day of germination test and expressed as a percentage. Seedling length of randomly selected 20 seedlings was measured at the $7^{\text {th }}$ day of the germination. Seedling vigour index was determined by multiplying the germination percentage and the seedling length as prescribed by Abdul Baki and Anderson (1973).

Field tests (seedling emergence) were conducted at the Post-control field of Seed Certification Service, Gannoruwa. Field experiment was conducted as Randomized Complete Block Design with three replicates. One hundred seeds per replicate were sown in well-pulverized soil and normal seedlings which emerged at $14^{\text {th }}$ day of the planting were counted and expressed as percentage of field emergence. Seed moisture content was determined by oven dry method according to ISTA guidelines (Fine grinded okra were kept in $130{ }^{\circ} \mathrm{C}$ for one hour).

Temperature and RH of the study locations was monitored using thermo-hygrometers. Maximum and minimum daily temperature, and morning and evening Relative Humidity values were obtained from the Natural Resources Management Center (NRMC) of Department of Agriculture, Sri Lanka. Agroclimatic zones in Sri Lanka are defined mainly by altitude and rainfall distribution pattern. Mid Country Wet Zone (MCWZ) is characterized by an altitude between 300 -
$900 \mathrm{~m}$ and with an annual rainfall of more than 2,500 mm. Mid Country Intermediate Zone (MCIZ) receives an annual rainfall between 1750 - $2500 \mathrm{~mm}$ with the same altitude as MCWZ. An altitude of less than $300 \mathrm{~m}$ with an annual rainfall less than $1750 \mathrm{~mm}$ represents the Low Country Dry Zone (LCDZ) (Punyawardhana, 2008).

The experimental design was Completely Randomized Design with three factor factorial (variety $\mathrm{x}$ location $\mathrm{x}$ time) arranged with three replicates. Data were analyzed using the SAS (Windows 9) statistical analytical package. The survival curves in two varieties under different storage conditions were analysed by probit analysis (Roberts and Ellis, 1989) and time in months that maintained the seed certification standards (75\%) as $\mathrm{p}_{75}$ was calculated by regression equation.

\section{RESULTS AND DISCUSSION}

Mean annual temperature and relative humidity in different storage conditions during the study period of two years are shown in Table 1 . The highest temperature was recorded at MahaIlluppallama.

\section{Seed germination}

Seed germination curves fitted by probit analysis of two varieties of okra stored at different storage conditions over 24 months are presented in Figure 1. Seeds of both okra varieties showed the high germination ability $(>85 \%)$ under constant low temperature (17 ${ }^{\circ} \mathrm{C}$ ) and RH over 24-month period of storage. The germinability of the seeds of both varieties stored at all the other high temperature locations, decreased drastically over time.

Two-way interactions between storage period*storage condition $(\mathrm{p}<0.0001)$, storage period*variety $(\mathrm{p}<0.0001)$ and storage conditions*variety $(\mathrm{p}<0.0001)$ significantly affected the germination of okra seeds. 
Table 1: Mean annual temperature and relative humidity at the storage locations during the study period of 24 months

\begin{tabular}{|c|c|c|c|c|c|c|}
\hline \multirow{2}{*}{ storage condition } & \multicolumn{2}{|c|}{$\begin{array}{c}\text { Mean annual T } \\
\left({ }^{\circ} \mathrm{C}\right) \\
\end{array}$} & \multirow{2}{*}{$\begin{array}{c}\text { Difference } \\
\text { between } \\
\text { Max and } \\
\text { min }\end{array}$} & \multicolumn{2}{|c|}{ Mean annual RH (\%) } & \multirow{2}{*}{$\begin{array}{c}\text { Difference } \\
\text { between } \\
\text { morning } \\
\text { and } \\
\text { evening }\end{array}$} \\
\hline & Max & Min & & Morning & Evening & \\
\hline $\begin{array}{l}\text { Low temperature } \\
\text { condition(LT) }\end{array}$ & $17^{*}$ & 17 & 0 & 65 & 65 & 0 \\
\hline Gannoruwa(MCWZ) & 30 & 21 & 8 & 79 & 70 & 9 \\
\hline Kundasale(MCIZ) & 31 & 21 & 10 & 78 & 65 & 12 \\
\hline Mahailluppallama(LCDZ) & 33 & 23 & 9 & 83 & 61 & 22 \\
\hline
\end{tabular}

*Standard deviations were within the $8 \%$, and are not shown here for clarity.

(A)

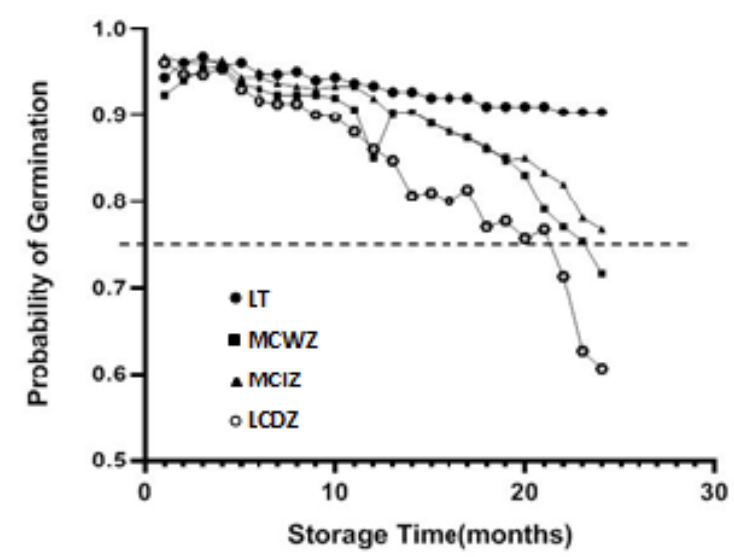

(B)

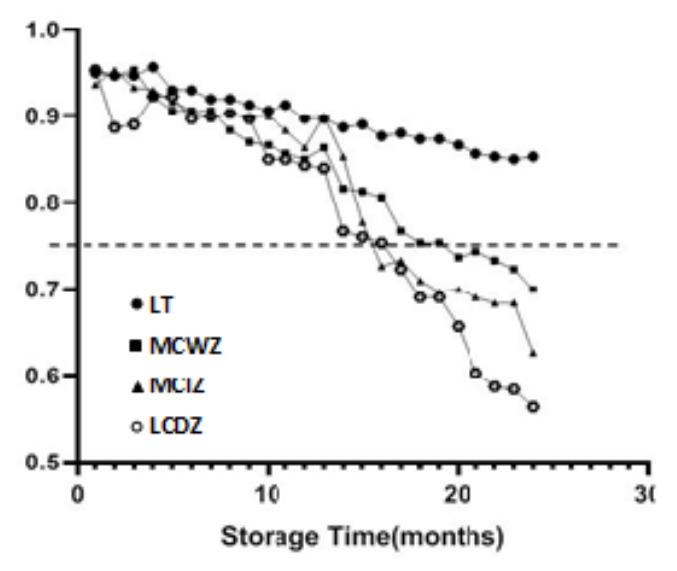

Figure 1. Effect of storage conditions on germination of okra seeds stored in retail packets during storage, expressed as the probability of germination fitted by probit analysis: A) MI-5 and B) Haritha. LT=Low temperature condition; MCWZ=Gannoruwa; MCIZ =Kundasale; MCDZ =Mahailuppallama. Dashed horizontal line shows the minimum seed certification standard 0.75 probability of germination.)

As reported previously, okra seeds generally have a higher longevity even under room temperature (Alhamdan and Alsadon, 2004). In the present study, when germination curves of seed lots of variety MI-5 and Haritha were compared under different storage conditions, time taken to reach the minimum seed certification standard for germination (i.e. $75 \%$, denoted as $\mathrm{p}_{75}$ ) derived from the probit plots of Figure 1, differed considerably (Table 2).

The $\mathrm{p}_{75}$ values for variety MI-5 were higher compared to variety Haritha irrespective of the storage conditions. In both varieties, the shortest time to reach the $\mathrm{p}_{75}$ was estimated to be at Mahallluppallama. The $\mathrm{p}_{75}$ at ambient storage conditions in Kundasale and Gannoruwa for each variety did not differ significantly. Under any condition, the longevity displayed by both varieties was far better compared to the results reported by Adam et al, (2017) under ambient conditions, which indicates the proper harvesting and processing practices at the official centres. 
Table 2: Time taken to reach the minimum seed certification standard for $(75 \%)$ germination ( $\left.p_{75}\right)$ derived from the probit plots of Figure 1, under different storage conditions for okra varieties MI-5 and Haritha

\begin{tabular}{lcccccc}
\hline \multicolumn{1}{c}{$\begin{array}{c}\text { Storage } \\
\text { Conditions }\end{array}$} & $\begin{array}{c}\text { Initial } \\
\text { Germination } \\
\%\end{array}$ & $\begin{array}{c}\text { Initial } \\
\text { moisture } \\
\%\end{array}$ & $\begin{array}{c}\mathrm{p}_{75} \\
\text { (months) }\end{array}$ & $\begin{array}{c}\text { Initial } \\
\text { Germination } \\
\%\end{array}$ & $\begin{array}{c}\text { Initial } \\
\text { moisture } \\
\%\end{array}$ & $\begin{array}{c}\mathrm{p}_{75} \\
\text { (months) }\end{array}$ \\
\hline $\begin{array}{l}\text { Low Temperature } \\
\text { condition (LT). }\end{array}$ & 94 & 10.0 & 79.7 & 93 & 10.5 & 44.1 \\
$\begin{array}{l}\text { Gannoruwa } \\
\text { (MCWZ) }\end{array}$ & 94 & 10.0 & 28.5 & 93 & 10.5 & 20.1 \\
$\begin{array}{l}\text { Kundasale } \\
\text { (MCIZ) }\end{array}$ & 94 & 10.0 & 31.3 & 93 & 10.5 & 17.4 \\
$\begin{array}{l}\text { Mahailuppallama( } \\
\text { LCDZ) }\end{array}$ & 94 & 10.0 & 19.2 & 93 & 10.5 & 14.8 \\
\hline
\end{tabular}

\section{Seed moisture}

Storage moisture and temperature are the key factors that determine the seed longevity (Alhamdan and Alsadon, 2004). When seeds are kept at different storage temperature conditions, the equilibrium relative humidity (ERH) helps to maintain an optimum equilibrium moisture content (EMC) in seeds. EMC and ERH are essential to minimize deterioration thereby to maintain a higher longevity (Vertucci \& Roos, 1993). According to Vertucci \& Roos (1993), the optimum moisture content in seeds increases as the storage temperature decreases. Similar study done by Demir et al (2016) on lettuce seeds showed that, viability of seeds remains high for a longer period with lower moisture content.

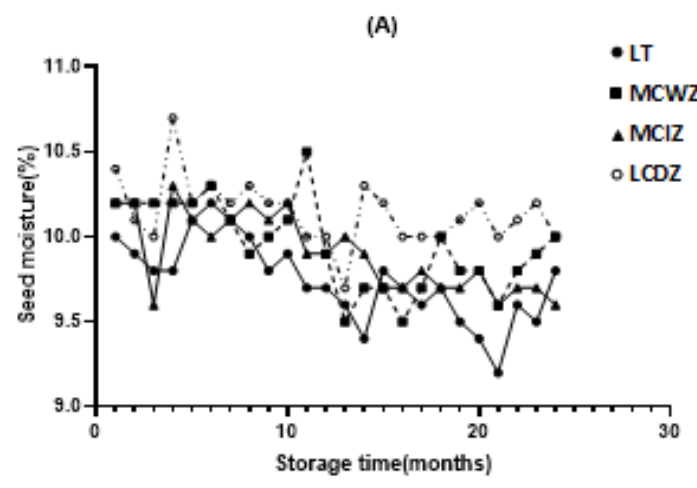

However, in the present study, there is hardly any chance for the equilibrium moisture content in seeds to fluctuate, because the okra seeds were packed and sealed in triple laminated aluminum foil packets. As illustrated in the Figure 2, the seed moisture content in both okra varieties did not vary significantly under four different storage conditions during the two-year period. At any given time during the experimental period, the seed moisture content ranged between 9$11 \%$, which complies with the seed certification standard for okra in Sri Lanka (i.e. $11 \%$ ) and as reported elsewhere (Rahman et al, 2017). Therefore, the seed moisture did not have any influence on the longevity of okra seeds.
(B)

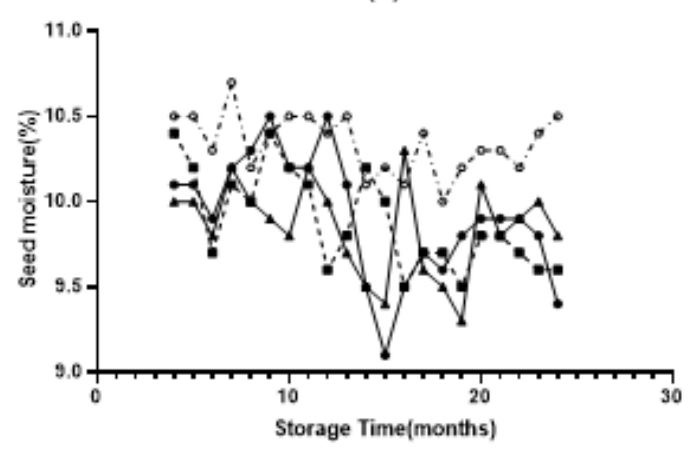

Figure 2. Effect of storage conditions on seed moisture content of okra seeds stored in retail packets, with time A) MI-5 and B) Haritha. LT=Low temperature condition; MCWZ=Gannoruwa ; MCIZ =Kundasale; LCDZ = Mahailuppallama 


\section{Field Emergence}

Depending on the storage conditions, the field emergence differed significantly (Table 3). There was a two way interaction effect of storage time*storage condition $(\mathrm{p}=<0.0001)$ and storage condition*variety $(p=<0.0001)$ which affected the field emergence percentage significantly. Seed germination and field emergence percentages at 12 and 24 months were significantly different irrespective of the variety and the location (Table 3 ).
Germination tests are used to evaluate the production of normal seedlings under optimum germination conditions (Atwater,1978; Geneve, 2008). However, standard germination test is not a good indicator of field emergence (Alillo, 2011) thus, these do not always reflect the field emergence potential of the seed lots (Morad, 2013).

Table 3: Effect of four different storage conditions on seed germination, field emergence and vigour index in okra verities at the end of 12 and 24 months

\begin{tabular}{llllllll}
\hline \multirow{2}{*}{$\begin{array}{l}\text { Storage } \\
\text { Conditions }\end{array}$} & Variety & & \multicolumn{2}{c}{ Seed germination\% } & \multicolumn{2}{c}{ Field Emergence\% } & \multicolumn{2}{c}{$\begin{array}{c}\text { Vigour index } \\
\text { (VI) }\end{array}$} \\
\cline { 3 - 8 } & & 12 & 24 & 12 & 24 & 12 & 24 \\
Low temperature & MI-5 & $93.3^{\mathrm{a}}$ & $90.3^{\mathrm{a}}$ & $84.0^{\mathrm{a}}$ & $70.6^{\mathrm{a}}$ & $1213.4^{\mathrm{a}}$ & $1008.6^{\mathrm{a}}$ \\
condition(LT) & Haritha & $89.6^{\mathrm{A}}$ & $85.3^{\mathrm{A}}$ & $81.3^{\mathrm{A}}$ & $75.0^{\mathrm{A}}$ & $1155.1^{\mathrm{A}}$ & $920.6^{\mathrm{A}}$ \\
Gannoruwa(MCWZ) & MI-5 & $85.0^{\mathrm{b}}$ & $71.6^{\mathrm{b}}$ & $76.0^{\mathrm{c}}$ & $52.6^{\mathrm{c}}$ & $1132.6^{\mathrm{ab}}$ & $809.9^{\mathrm{b}}$ \\
& Haritha & $85.0^{\mathrm{A}}$ & $70.0^{\mathrm{B}}$ & $81.3^{\mathrm{A}}$ & $43.3^{\mathrm{C}}$ & $1035.5^{\mathrm{AB}}$ & $814.2^{\mathrm{AB}}$ \\
Kundasale(MCIZ) & MI-5 & $92.0^{\mathrm{a}}$ & $76.6^{\mathrm{b}}$ & $79.3^{\mathrm{b}}$ & $62.3^{\mathrm{b}}$ & $1118.8^{\mathrm{ab}}$ & $760.0^{\mathrm{b}}$ \\
& Haritha & $86.3^{\mathrm{A}}$ & $62.6^{\mathrm{C}}$ & $76.6^{\mathrm{A}}$ & $57.0^{\mathrm{B}}$ & $1051.2^{\mathrm{AB}}$ & $686.3^{\mathrm{BC}}$ \\
Mahailuppallama(LCDZ) & MI-5 & $86.0^{\mathrm{b}}$ & $60.6^{\mathrm{c}}$ & $81.0^{\mathrm{ab}}$ & $50.3^{\mathrm{c}}$ & $1030.8^{\mathrm{b}}$ & $588.0^{\mathrm{c}}$ \\
& Haritha & $84.3^{\mathrm{A}}$ & $56.3^{\mathrm{D}}$ & $73.3^{\mathrm{A}}$ & $38.0^{\mathrm{C}}$ & $952.9^{\mathrm{B}}$ & $515.3^{\mathrm{C}}$ \\
\hline cV\% & MI-5 & 2.98 & 4.02 & 2.67 & 6.84 & 6.52 & 6.16 \\
& Haritha & 5.40 & 4.49 & 6.14 & 11.83 & 6.13 & 13.05 \\
\hline
\end{tabular}

Means with the same superscript letters within columns are statistically non-significant at 5\% level of probability (DMR test). Please note the upper case and lower case letters for two different varieties to compare within columns.

\section{Vigour index (VI)}

Seed vigour index (VI) is a widely accepted measure of seed and seedling vigour of a particular seed lot (Usha and Dadlani, 2015). In the present study, the storage condition, storage time and variety interactively affected significantly on the vigour index of okra seeds $(p=<0.0001)$. Higher VI was observed in seeds stored at constant low temperature and $\mathrm{RH}$ conditions compared to those stored at fluctuating temperature and $\mathrm{RH}$.

Basic objective of vigour testing is to provide a consistent identification of differences in physiological potential among seed lots and this signifies a more sensitive parameter than the germination test alone (Marcos-Filho, 2015). Seeds with high vigour better able to withstand storage conditions with any form of stress (e.g. changes in temperature or relative humidity in ambient storage conditions) and decline in quality at a slower rate than seeds with lower vigour. Performance after storage depends on the vigour status of the seed lot even under controlled storage conditions (ISTA, 2009).

In a previous study of Rao et al (2006), the effect of storage conditions on viability and vigour of onion seeds was studied and they reported that a complete pattern of loss in viability could be understood on the basis of 
seed moisture and storage temperature. In addition, they explained that seed viability and vigour decreased due to increased lipid peroxidation and decreased activities of several free radical and peroxide scavenging enzymes. In the present study, a similar rapid decline in seed quality was observed in okra seeds in the ambient climate regimes where

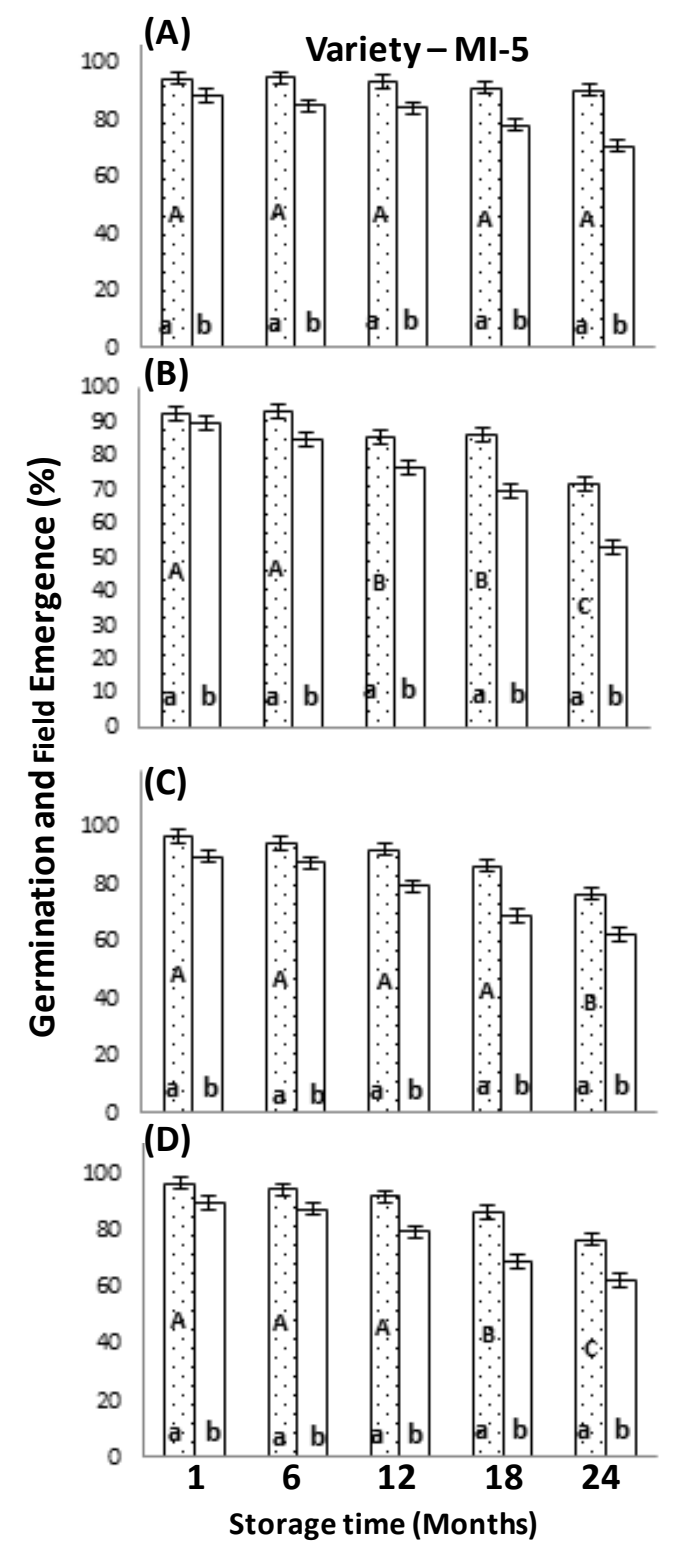

high temperature and RH prevailed compared to that in the low temperature condition (Table 2). Since the seeds were in triple laminated packing, seed moisture variation was not a factor. Yet, the importance of seed storage temperature alone on storage life and seed quality parameters; germination and vigour was prominent.

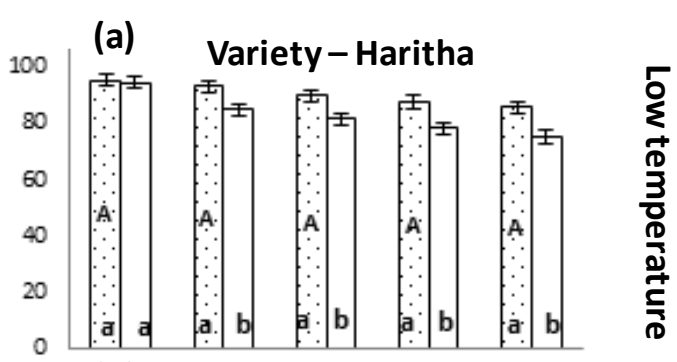

(b)

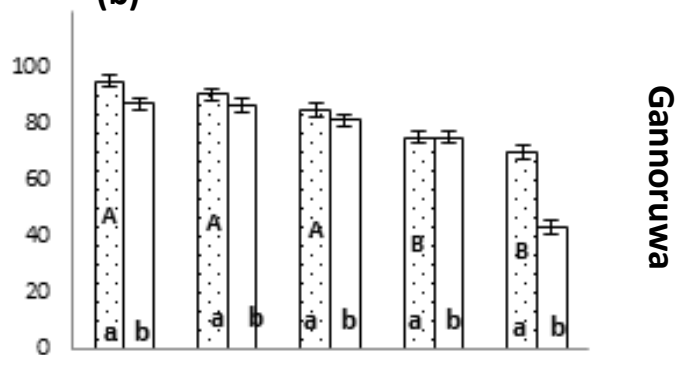

(c)
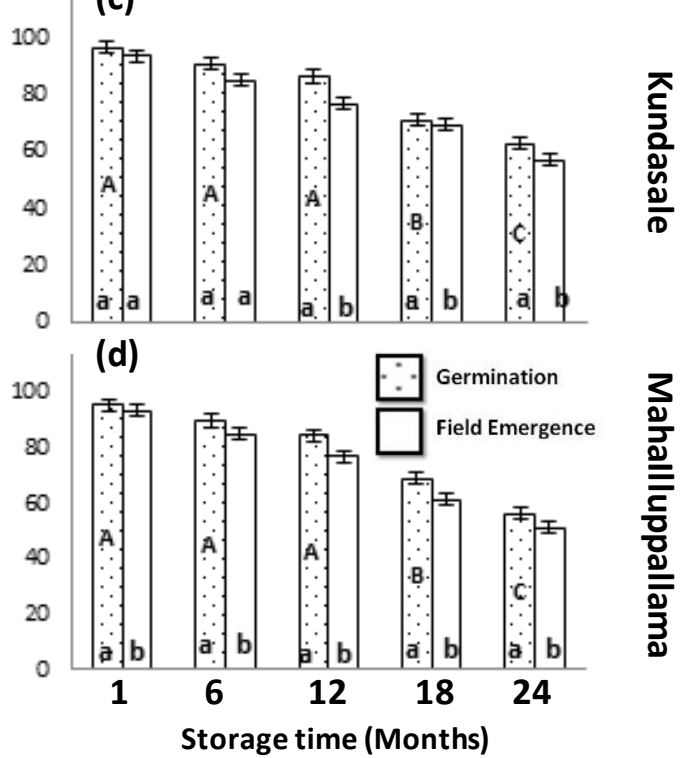

Figure.3. Changes of Laboratory germination and Field emergence percentages in varieties MI-5 $(A, B, C, D)$ and Haritha (a,b,c,d) at four different storage conditions with storage time. A and a: Low temperature condition (LT); B and b: Gannoruwa(MCWZ); C and c: Kundasale(MCIZ); D and d: Mahailuppallama(LCDZ). (T1-after 1 month,T6-after 6 months, T12-after 12 months, T18-after 18 months, T24- after 24 months). Different Uppercase letters within a germination show significant difference between storage time and different lowercase letters show significant differences between Germination and FE with the time period at $\mathrm{p}=0.05$ level. 
Relationship between the germination and field emergence

A comparison of germination percentage and field emergence percentage of two varieties of okra under different storage conditions over the experimental period is presented in the Figure 3. Field emergence percentage of seeds was significantly different with laboratory germination values even when the seeds were stored under controlled temperature and $\mathrm{RH}$ conditions. Germination and field emergence percentage did not differ in the first month of seeds of variety Haritha under the controlled low temperature condition and first three month of the ambient temperature and $\mathrm{RH}$ conditions in Kundasale. This behavior may be a varietal character fitting to the prevailing conditions. Understanding of the behavior of seed quality parameters with time is very complex as detailed by Walters (2007).

As well understood, germination test results do not provide sufficient information to the farmers and do not guarantee the field performances of seeds, especially when the seeds are stored for a longer duration under fluctuating environmental conditions even inside a sealed packet. Even though the packing material has a strong influence on the seed deterioration at storage, particularly in relation to moisture absorption (e.g. Sultana et al, 2016), in the present study, the packaging materials did not allow any moisture absorption. Therefore, the observed deterioration in the okra seeds after 24 months was may be due to the temperature fluctuations at the high-end. Except under low temperature storage, the field emergence was less than $60 \%$ in all the other locations for both varieties.

Results of the present study revealed that, both varieties of okra seeds can be stored under ambient conditions at Gannoruwa, Kundasale or Mahallluppallama for a maximum period of 12 months, without compromising the seed quality(germination and field emergence $>70 \%$ ). If the seeds are stored under low temperature conditions (i.e. $17^{\circ} \mathrm{C}$ ), the seed quality can be maintained for a period of 24 months.

\section{CONCLUSION}

Initial germination and moisture 94\%,10 and 93, 10.5 of two varieties of Okra; MI-5 and Haritha packed in triple laminated aluminum packets and stored in a low and constant temperature and $\mathrm{RH}$ storage condition was the most suitable for prolonged storage. A storage condition where temperature is between 29 $32{ }^{\circ} \mathrm{C}$ and $\mathrm{RH}$ is between $63-77 \%$ at kundasale (MCIZ) is the second most suitable place to store seeds for a considerable time for variety MI-5. Variety Haritha seeds best suited for Gannoruwa (MCWZ). Mahailuppallama (LCDZ) where the temperature between 21 $34{ }^{\circ} \mathrm{C}$ and $\mathrm{RH}$ between $52 \%-87 \%$ was recognized as a 'not suitable' storage environment for prolonged storage.

Seed germination does not represent the potential field emergence percentage. Seed vigour changes with the change in storage environment and variety. Seed lots of okra stored beyond one year, need to validate by field germination in relation of seed vigor before issuing for commercial farming.

\section{ACKNOWLEDGMENTS}

Prof. L.D.B. Suriyagoda is gratefully acknowledged for the guidance in statistical analyses.

\section{REFERENCES}

Abdul Baki, A.A., and J.D. Anderson. (1973). Vigour determination of Soy bean seeds by multiple criteria. Crop Sci., 13: 630http://dx.doi.org/10.2135/cropsci1973.0011 183X001300060013X 
Adam, O., Sunday, A., Mayowa, O., Gloria, A. and Olabisi, 0. (2017). Effects of Storage Conditions and Duration on Seed Germination of Okra (Abelmoscus esculentus). International Journal of Plant \& Soil Science. 20(6): 1-6. DOI:https://doi.org/10.9734/IJPSS/2017/ 38518

Alhamdan, Abdullah and Alsadon, Abdullah. (2004). Moisture sorption isotherms of four vegetable seeds as influenced by storage conditions. Acta Horticulturae. 631, 63-70. DOI:10.17660/ActaHortic.2004.631.7.

Aliloo, A., and Shokati, B. (2011). Correalion between seed tests and field emergence of two maize hybrids (SC 704 and Sc500). Online Journal of Animal and Feed Research. 1(6):249-254.

Atwater, B.R., (1978). Dealing with stop-go germination in flower seeds. Acta Hort. 83,175-179

Department of Census and Statistics (2018) Highland Crops. Available at http://www.statistics.gov.lk/agriculture/hcr ops/index.html [accessed on 02.04.2019]

Demir, I., Celikkol, T. Sankamis, G. and Eksi, C. (2011). Vigor tests to estimate seedling emergence potential and longevity in Viola seeds. HortScience. 46(3):402-405. Doi https://doi.org/10.21273/HORTSCI.46.3.402

Ellis, R.H. (1991). The longevity of seeds. Hort Science 26 (9):1119-1125.

Geneve., R.L.(2008). Vigour testing in small seeded horticultural crops. Acta Hortic. 782, p.77-82.DOI:10.17660/ActaHortc. 2008.782.6

Gómez-Campo, C. (2006). Erosion of genetic resources within seed gene banks: the role of seed containers. Seed Science Research, 16(04): 291-294.

ISTA (2009): International Rules for Seed Testing. International Seed Testing Association, Switzerland

ISTA (2015), International Rules for seed Testing vol 2015, introduction i-9A4

Marcos-Filho, Julio. (2015). Seed vigor testing: an overview of the past, present and future perspective. Scientia Agricola, 72(4): 363-374. https://dx.doi.org/10.1590/0103-90162015-0007.

Morad., Shaban.(2013). Study on some aspects on seed viability and vigour. International journal of Advanced Biological and Biochemical Research. 1(12):1692-1693. [online] available at http://www.ijabbr.com [accessed on10.06.2019]

Punyawardhana., B.V.R. (2008). Rainfall and Agro ecological zones of Sri Lanka (Sinhala):31-40.

Rahman., M.H., Sattar, M.A., Salim, M.M.R., Quddus, M.A. and Ali, M.M., (2017). Study on Quality of Okra (Abelmoschus esculentus L.) Seed Collected from Different Sources and Locations of Bangladesh. American Journal of Plant Biology, 2(4), pp.129-135.

Rao., R. G. Singh, S. P.M, and Rai, (2006). Storability of onion seeds and effects of packaging and storage conditions on viability and vigor. Scientia Horticulture,(110):1-6

Roberts., E.H. and R.H. Ellis. (1989).water and seed survival. Annals of Botany. .63,39-52

Singh J., Paroha S. and Mishra, R.P. (2017). Factors affecting oil seed quality during storage with special reference to Soybean 
(Glycine max) and Niger (Guizotia abyssinica) seeds. International Journal of Current microbiology and Applied Sciences. ISSN: 2319-7706. Vol (10): 22152226.https://doi.org/10.20546/ijcmas.2017. 610.262 .

Sultana R, Chowdhury MSM, Islam MR, Akhter K. (2016) Effect of container and duration of storage on the quality of okra (Abelmoschus esculentus) seeds. The Agriculturists. 14(1):63-72.

Usha., T.N. and Dadlani, M. (2015). Evaluation of seed vigour in soybean (Glycine max). Agric Res Commun Cent J. 38(3), pp.308-12.

Vertucci., C. \& Roos, E. (1993). Theoretical basis of protocols for seed storage II: The influence of temperature on optimal moisture levels. Seed Science Research, 3(3): 201-213. doi:10.1017/S0960258500001793

Walters, Christina and Roos, Eric. (1990). Theoretical Basis of Protocols for Seed Storage. Plant physiology. 94, 1019-23. DOI: 10.1104/pp.94.3.1019.

Walters, C. (2007). Materials used for seed storage containers: response to Gómez Campo [Seed Science Research 16, 291-294 (2006)]. Seed Science Research, 17(04): 233-242.

Yanping., Y. Rongqi, G. Qinguan, S. and Shengfu, L. (2000). Effect of storage temperature and container type of on the vigour of Welsh Onion seeds with low moisture content. Australian J. Experimental Agri. 398,1025-1028 